\title{
Sinemanın Özüne Bir Yolculuk: “Saf Sinema” Olgusunu Tartışmak ve Bir Örnek Olarak Yol Kenarı Filmi
}

\author{
Mert Can Arık*
}

\section{Özet}

İlk olarak 1920'lerde Fransiz-Avangart sinemactlarca önerilen, o zamandan beri de film yapımcları, yönetmenleri ve sinema akademisi tarafindan tartışılan saf sinema kavramı, oldukça belirsiz ve çerçevesi zor çizilen bir kavram olarak karşımızda durmaktadır. Ancak tüm bu tartışmalı noktada dahi saf sinemanın film yapımındaki diğer sanatsal medyumların bilinçli olarak reddedilmesi, özellikle edebiyatın anlatı üzerindeki etkisiyle; tiyatronun, olay örgüsü ve oyunculuk üzerindeki etkisinin kabul edilmediği bir sinema anlayışı olduğu ortaklaşılmış bir noktadır. Bu bağlamda saf sinema, temel olarak sadece sinemanın olanaklar ile sinema yapmak anlamına gelen bir kavram olarak karşımıza çıkar. Başka bir değişle bu sinema sanatının kendine özgü, kendine has özelliklerini kullanarak film yapması anlamına gelmektedir. Bu çalışma felsefi bir yolculukla Bela Balazs'ın sinemayı özgünleştiren anlayışı, Siegfried Kracauer'un sinematik yaklaşım kavramı ve Gilles Deleuze'ün hareket imge ve zaman imge kavramları çerçevesinde betimleyici bir yöntemle saf sinema yaklaşımını tanımlamaya çalışacak ve bu yaklaşımın Türk Sineması'nın son dönemlerinde nasıl görünür olduğunu film analizi yöntemlerinden biçimsel analiz yöntemiyle Yol Kenarı (Tayfun Pirselimoğlu, 2017) filmindeki saf sinemaya özgü sinematografik kodları çözümleyerek tartışmaya sunacaktır. Bu noktada araştırmanın temel amacı saf sinemanın sınırlarını tartışmak ve tanımlanan sinema anlayışının film yapma pratiklerini somut bir şekilde ortaya koymaktır.

Anahtar Kelimeler: Saf Sinema, Sinematik Yaklaşım, Gilles Deleuze, Hareket ve Zaman İmge, Yol Kenarl.

* ORCID: 0000-0001-5123-3347

E-Mail: mertarik1@gmail.com

DOI: $10.31122 /$ sinefilozofi.672407

Received - Geliş Tarihi: 10.01.2020

Accepted - Kabul Tarihi: 30.04.2020 


\title{
A Journey To The Essence Of Cinema: Discussing The Case Of 'Pure Cinema' and Sideway Frlm As An Example
}

\author{
Mert Can Arik*
}

\begin{abstract}
The concept of pure cinema, which was first proposed by the French-Avant-garde filmmakers in the 1920s, and has since been discussed by filmmakers, directors and film academies, stands as a rather vague and difficult-to-frame concept. However, even at all this controversial point, the conscientious rejection of pure cinema by other artistic mediums in filmmaking is a common point, especially with the influence of literature on narrative, and that theater is an unacceptable understanding of cinema, on the plot and on acting. In this context, pure cinema is basically a concept which means making cinema with only the possibilities of cinema. In other words, this means that the art of cinema is making films by using its own unique features. This study will attempt to define the pure cinema approach by using a descriptive method within the framework of Bela Balazs' understanding of cinema, Siegfried Kracauer's concept of cinematic approach and Gilles Deleuze's motion image and time image will be presented to the discussion by analyzing the cinematographic codes specific to pure cinema in the film Sideway (Tayfun Pirselimoğlu, 2017). At this point, the main purpose of the research is to discuss the limits of pure cinema and to present the filmmaking practices of the defined cinema understanding in a concrete way.
\end{abstract}

Key Words: Pure Cinema, Cinematic Approach, Gilles Deleuze, Motion and Time Image. Yol Kenar

\footnotetext{
* ORCID: 0000-0001-5123-3347

E-Mail: mertarik1@gmail.com

DOI: $10.31122 /$ sinefilozofi.672407

Received - Geliş Tarihi: 10.01.2020

Accepted - Kabul Tarihi: 30.04 .2020
} 


\section{Giriş}

Saf sinema kavramını birçok noktadan ele alabilmek ve kavram hakkında farklı konumlanma noktasından tartışmalar yapabilmek mümkündür. Bunlar sinemanın dışındaki sanat ve estetik alanından dayanaklar olabileceği gibi sinemanın içinden farklı kavramlar ve akımlar da olabilir. Bu haliyle saf sinema olgusu, ilk bakışta sınırları net çizilemeyen ve karmaşık bir alan olarak karşımıza çıkmaktadır. Ancak tüm bu belirsizliğe rağmen saf sinema kavramının kendisi bile bize bazı ipuçları verebilmektedir. Saf sinema 'saf olan' ile ilgilidir. Bir 'şey'in safı ise ya onun özünde, ya ilk örneklerinde yatmakta ya da süreç içerisinde bu özün korunmasıyla sağlanmaktadır. Ancak tüm bunların ötesinde saf sinema aslında en genel anlamiyla sinemanın olanakları ile sinema yapmak olarak tanımlanmaktadır. Başka bir değişle bu sanatın kendine özgü, kendine has özelliklerini kullanarak film yapması anlamına gelmektedir. Bu tanımlama genel anlamıla doğru ve kapsayıcı olmasına karşın son derece muğlaktır. Muğlak olması: Sinemanın olanakları olarak tanımlanan olanaklar nedir? Sinemanın kendine has özellikleri nelerdir? Çerçevesi çizilmeye çalışılan sinema neden saf olarak nitelendirilmiştir? Saf olarak nitelendirilen sinemaya nasıl bir düşünsel yolla kavramsal olarak ulaşılabilir? gibi birçok soruyu cevapsız bırakmasından kaynaklanmaktadır. Bu çalışma bu eksik sorulardan hareketle yapılan tanımların dışına çıkarak ve bu eksik soruları filozofik bir yolculukla sorarak saf sinema olgusunu tartışmaya açacaktır. Bu anlamda çalışmanın temel konumlanma noktası saf sinemanın ancak sinemanın özüne yapılan ontolojik bir yolculukla tartışılabileceği görüşüdür. ${ }^{1} \mathrm{Bu}$ yolcuğun sonucundan ulaşılacak öz, saf sinemayı tartışırken önemli bir merkez oluşturacak ve tartışmalı bir olgunun netleşmesine olanak sağlayacaktır. Başka bir değişle sinemanın özü, kilitli duran saf sinema sandığını açan bir anahtar olarak karşımıza çıkacaktır.

Saf sinema üzerine düşünürken bu sinemanın özüne yapılan bir yolculukla ele alınacaksa kavramın ilk olarak nasıl ve ne şekilde tartışıldığı noktasına da değinmek yerinde olacaktır. Saf sinema kavramı ilk olarak 1920'lerde Avrupa'da Fransız Avangard sinemacilar tarafından tartışılmaya başlanmıştır. Deneysel sinemacılar olarak da anılan bu akımın üyeleri saf sinemayı 'cinema pur' olarak kavramsallaştırmıştır. Avangard sinemacılar o dönemde ticari sinemadan bir kopuş göstermiştir. Bunun en büyük nedeni o dönemde sinemaya yavaş yavaş hâkim olan oyun ve roman uyarlamalarıdır. Avangard sinemacılara göre tiyatronun ve romanın hikâye özelliği sinema sanatında hâkim anlayış olmamalıdır. Böyle olması sinema sanatı için dışarıdan yapılan bir zorlamanın ötesine geçemeyecektir. Çünkü bu durum sinema sanatının özüne ters düşmektedir. Saf sinema kavramını ilk olarak tartışan bu grup açıkça hikâyeli filme karşı bir isyan olarak ortaya çıkmıştır (Kracauer, 2015: 363).

Saf sinema kavramı sinemanın özüne yapılan bir yolculukla tartışılmaya açıldığından bu yolda elbette ki bazı duraklarda kaçınılmaz olarak durmak gerekecektir. Saf sinema kavramı tartışılırken ilk olarak Bela Balazs'ın sinemayı özgürleştiren düşünceleri, ardından Siegfried Kracauer'nun Sinematik Yaklaşım'ı ve bunun yanında Kaydetme ve İşa Etme İşlevleri bir başka temel noktayı oluşturur. Ardından son olarak sinema ve felsefe köprüsü denildiğinde ilk akla gelen isimlerden Gilles Deleuze'ün sinemanın temellerini oluşturan

\footnotetext{
${ }^{1}$ Metin içinde saf sinemanın tanımlanması yerine tartışılması kavramı bilinçli olarak kullanılmaktadır. Tartışma kavramının, konunun belirsizliği için daha uygun olduğu ve çalışmanın konuyu tartışma amacında olmasından ötürü daha yerinde olduğu düşünülmektedir. Ancak tartışmanın sonunda yine de eldeki verilerden kavramın netleştirilmesi adına bir tanımlanma yapılmaya çalışılacaktır.
} 
Hareket İmge ve Zaman İmge kavramlarını konu bağlamında ele alınacaktır. Saf sinema tartışılırken çalışmanın kuramsal çerçevesi ve sınırlılı̆̆ını bu kuramcılar ve onların düşünceleri oluşturacaktır. Bunun yanı sıra Dogma 95 akımının da saf sinema ile ilişkisi irdelenecektir.

Çalışma "saf sinema kavramına sinemanın özü tartışılarak ulaşılabilir" ve "saf sinema kavramında temel nokta görüntü imajlardır" varsayımlarına dayandırılmıştır. Daha sonra elde edilen veriler doğrultusunda saf sinemanın izlerini Türk sinemasının son dönem örneklerinden Tayfun Pirselimoğlu'nun Yol Kenarı (2017) filmi üzerinden somutlaştırmaktır. Örneklem olarak Yol Kenarı filminin seçilmesinin sebebi filmde gerek görüntülerin merkezi konumda kullanılması gerekse sinematik unsurların tutumlu kullanılmasından ötürü ortaya çıkan saf sinema ritmi etkili olmuştur.

Çalışmanın amacı ilk olarak sınırları, çerçevesi net olarak çizilmemiş ve çok az ele alınmış bir konu olan saf sinema kavramını tartışmaya açarak kavramın neye karşılık geldiğini, hangi konumlanma noktalarından ele alınabileceğini ortaya koymak ve mümkünse tartışma sonucunda kavramın sınırlarını netleştirmektir. Tüm bu veriler betimleyici bir yöntemle ele alınacak ardından film analizi yöntemlerinden biçimsel analiz yöntemiyle film analiz edilerek saf sinemaya dair fikirler ortaya koyulacaktır. Ayrıca çalışmaya yönetmen Tayfun Pirselimoğlu ile yapılan kısa görüşme eklenerek konuya yönetmenin bakışı açısı da dâhil edilecektir. Bu şekilde konu çok perspektifli bir bakış açısıyla sunulmaya çalışılacaktır. Yönetmenin görüşleri konunun bağlamı dışında kalan saf sinema ve seyirci ilişkisi konusuna da ışık tutması bakımından önem arz etmektedir.

Tüm bu bilgiler 1şığında çalışmanın ilk üç bölümünü saf sinemaya ulaşmada kilit önem taşıyan Bela Balazs, Siegfried Kracauer ve Gilles Deleuze'ün sinemanın özüne dair düşünceleri oluşturmaktadır. Ardından gelen iki bölümü ise Dogma 95'in saf sinemayla olan ilişkisi ve Tayfun Pirselimoğlu'nun konuya dair düşünceleri oluşturmaktadır. Altıncı bölümde ise örnek olarak seçilen Yol Kenarı filmi analiz edilecektir. Son olarak tüm bu veriler sonuç bölümde tartışılarak çalışma sonlandırılacaktır.

\section{Bela Balazs'ın İzinde Saf Sinemayı Aramak}

Sinemanın sessiz döneminin en önemli kuramcılarından olan Alman Bela Balazs Görünen İnsan (2013) isimli yapıtında genel olarak sinemanın tıpkı resim, heykel, müzik ve tiyatro gibi bir sanat olduğunu kanıtlamaya çalışmıştır. Bunu yaparken de sinemayı bu yukarıda adı geçen sanatlarla karşılaştırma yoluna gitmiştir. Örneğin resim sanatının veya tiyatronun öne çıkan, kendine özgü özellikleri ile sinemayı karşılaştırmıştır. Bunu yaparak aslında sinema sanatının kendine özgü özelliklerini de ortaya çıkarmayı amaçlamıştır. Sonuç olarak diğer sanatlar ile sinemayı karşılaştırma yoluna giderek sinemayı diğer sanatlardan ayıran özellikleri belirlemiş ve sinemanın bu kendine has özellikleri ile sinemanın kendi başına ayrı bir sanat olduğu kanıtlamıştır. Balazs'ın sinemanın özünü arama çabası ve bu yoldaki fikirleri saf sinema tartışmamız açısından son derece önem arz etmektedir. Ayrıca onun konu bağlamında önemli olmasının bir diğer nedeni sinema sanatının kendine özgü özelliklerini belirlemesi ve bunun hayati öneminden bahsetmesidir. Özellikle saf sinema kavramını tartışmamızda ve bu olguyu temellendirmemizde belki de çıkış noktasını oluşturacak şekilde Balazs, Görünen İnsan eserinde şu ifadelere yer verir; "Her sanatın meşruiyeti, yeri başka bir şeyle doldurulamaz bir ifade imkânı olmasında yatar" (Balazs, 39: 2013). 
Balazs'ın bu düşüncesi aslında hemen hemen eserlerinin çoğunda ifade etmek istediği fikirlerin özeti niteliğindedir. Burada aslında sinema sanatının sadece kendine ait, temel oluşturan, yeri doldurulamaz bir özelliği olmasının zorunlu olduğu anlayışı vardır. Çünkü herkes tarafından kabul gören ve sanat olduğu artık tartışma götürmeyen alanların hepsinde yeri başka bir şeyle doldurulamayan bir ifade biçimi vardır ve bu sebeple bu alanlar kendi başlarına bir sanattır. Dolayısıyla bu ifade hem sinemanın kendi başına bir sanat olarak var olması hem de bu mecranın yani sinemanın özünün sorgulanması ve belirlenmesi için önem arz etmektedir.

Saf sinema tartışmasına bu bağlamda yaklaşacak olursak; sinemada yeri doldurulamaz olan ifade biçimi nedir? Veya başka bir şekilde soracak olursak sinemadan hangi medyum, unsur veya özellikler çıkarılırsa hala sinema yapılmaya devam edebilir? İşte bu soruların cevabı bizi Balazs'ın izinde bir saf sinema yolculuğuna çıartmaktadır ve bu bağlamda kavramın sınırlarını çizmemiz konusunda bize yol göstermektedir. Buradan hareketle sinemada yeri doldurulamaz dediğimizde aklımıza birçok şey gelebilir. O sebeple ikinci sorudan hareketle ilerlemek yerinde olacaktır. Sinemadan hangi ifade imkânını çıkarırsak yeri doldurulamaz veya hangi ifade imkânını çıkarırsak yeri doldurulabilir? Sorulara cevap arayarak geriye doğru bir sorgulama yaptığımızda birçok medyum karşımıza çıkmaktadır.

Renk konusu bunlardan bir tanesidir. Renk sinemada özellikle günümüzde görüntünün vazgeçilmez unsurlarından biri olarak karşımıza çıkar. Yönetmenler anlam yaratmak için sinemada rengi estetik ve etkisel amaçlarının dışında da kullanmaktadırlar. Ancak sinemanın ilk yıllarında olduğu gibi filmler pekâlâ renksiz -siyah-beyaz- da olabilmektedir. Hatta günümüz sineması da bazı durumlarda anlam yaratmak için siyahbeyaz renk kullanımı tercih edilebilmektedir. Bunun en güncel ve başarılı örneği Roma (Alfonso Cuaron, 2018) filmidir. Roma filmi 2000'li yıllarda, teknik aksaklıklardan ziyade yönetmenin bilinçli tercihi sebebiyle siyah- beyaz olarak çekilmiştir. Yönetmen bu renk tercihiyle sinematografinin daha çok öne çıkmasını sağlamıştır. Diğer bir taraftan rengin anlam yaratmak amacıyla etkili bir şekilde kullanıldığı bir örnek de Krzysztof Kieślowski'nin Bleu (Mavi, 1993), Blanc (Beyaz, 1994) ve Rouge (Kırmızı, 1994) filmlerini kapsayan "Trois Couleurs" üçlemesidir. Kieślowski bu üçlemesinde renkleri, her bir filminde renklerin yarattığı farklı anlamlarla bağdaştırarak filmin temel noktası haline getirmiştir. Yani hangi amaçla kullanılırsa kullanılsın renk sinemada bir tercih durumuna gelebilmektedir. Bu doğrultuda renksiz -siyah- beyaz- de sinema mümkün görünmektedir. Bu noktada rengin sinemaya dâhil olup olmamasının gerekliliği başka bir konunun tartışma alanını oluşturur. Sonuç olarak renk sinemada yeri doldurabilir bir ifade imkânı olarak karşımıza çıkar.

Ses yine doğal kullanımının haricinde sinemada dramatik etkiyi arttırmak için kullanılan sinemanın kendini ifadesinin başka bir aracıdır. Değinildiği gibi ses filmde doğal bir şeklide bulunduğu gibi Pyscho (Sapık, Alfred Hitchcock, 1960) filmindeki duş sahnesinde olduğu gibi gerginlik unsuru tetikleyen bir unsur olarak etki yaratılmak için de kullanılabilir. Bunun dişında Apocalypse Now (Kıyamet, Francis Ford Coppola, 1979) filminde vantilatörün pervane sesinin helikopter sesine bağlanması yine sesin kullanımı için önemli örnekler arasındadır. Burada sesin farklı kullanımlarına değinilirken filmlerin tamamen sessiz bir şekilde olabileceği de pekâlâ bilinmektedir. Bunun yine en büyük örneği sinema tarihinin ilk yıllarındaki başyapıtlardır. Veya günümüzde de tamamen sessiz olmasa da sesin çok 
minimal kullanımları ile karşılaşılmaktadır. O halde sinema sanatında yeri doldurulamaz olan ifade imkânının ses olmadığı da söylenebilir. Diyalog da sinema sanatı için tıpkı ses gibi yeri doldurulabilir bir araçtır.

Dramatik aydınlatma yine sinemanın bir başka ve önemli bir unsurudur. Filmde gözümüze çarpan 1şıklar elektronik bir güç kaynağından olabileceği gibi doğal bir aydınlatma kullanılarak da yapılabilmektedir. Burada bahsedilen kapalı veya açık ortam fark etmeksizin kullanılan yapay aydınlatmadır. Sinemada yapay ışık kullanılmadan da sinema yapılabileceği zaten daha önceden de dile getirilmiş ve uygulanmıştır. Bunun izlerini Yeni Dalga sineması ve Dogma 95 sinemasında görmek mümkündür. O halde bahsedilen ışık yöntemleri kullanılmasa da sinema yapmak olanaklıdır.

Sinemada müzik sinemanın ilk yıllarından günümüze kadar uzanan geniş bir kullanım alanına sahiptir. Sinemanın sessiz olarak adlandırılan döneminde de müzik diyaloglara/konuşmalara rastlamasak da sinemada kendine yer bulmuştur. Ayrıca sadece estetik olarak değil anlatımı destekler niteliklerle de sinemada kullanılmıştır. Sinemada müziğin olmayışı tıpkı yukarıda belirttiğimiz sinemanın diğer anlatım olanakları gibi çok büyük ve etkili bir öneme sahiptir. Ancak hiçbiri son tahlilde yeri doldurulamaz bir ifade imkânı değildir. Sinemaya dair daha birçok özellik veya unsur sayılabilir fakat bütün bunlar yukarıda belirttiğimiz gibi çok büyük önem arz etmelerine rağmen en nihayetinde sinema için vazgeçilmez bir ifade imkânı değildir. Burada tüm bu araçların dışında yeri doldurulamaz ifade imkânı olarak görüntü imajların karşımıza çıktığı görülmektedir.

Balazs'ın her sanat için söylediği yeri başka şeyle doldurulamaz ifade imkânı olan şey sinemanın özüne yapılan bir yolculukla sinema sanatı için görüntüler olarak karşımıza çıkmaktadır. Bahsedilen tüm unsurlar olmasa da olabilir veya onun yeri bir başka sinematik araçla doldurulabilir bir durumdadır. Ancak sinemanın özünü oluşturan görüntüler olmadan sinema olanaksizdir.

Bu tartışılanların en nihayetinde bizi götürdüğ ü noktalardan biri belgeselvari bir film biçimidir. Tüm bu ifade araçları ve teknik altyapı çıkarıldığında harekete dayalı bir görüntü kalacaktır. Bu da belge niteliğinde Nonook of the North (Kuzeyli Nanook, Robert J. Flaherty, 1922) veya La Sortie des Usines Lumière à Lyon (Lyon'daki Lumière Fabrikasından Çıkan İşçiler, Lumière Brothers, 1895) benzeri filmlere karşılık gelen bir alan oluşturur. Ancak sinemanın sanatsal boyutu düşünüldüğünde bu tarz filmler bize saf sinema konusunda önemli bir fikir verse de bu kavramı tam olarak karşılamamaktadır. Çünkü sinemanın gelişimiyle kurgusal türler de gelişmeye başlamıştır.

Bakıldığında ortaya atılan görüşlerin tarif ettiği film biçimi aslında sinemanın ilk yıllarında üretilen filmlere denk düşmektedir. Ancak bunun bilinçli bir tercihten öte sinema teknolojisinin o yıllardaki gelişmişlik seviyesi sebebiyle ortaya çıktı̆̆ı açıktır. Zaten sinema teknolojisinin gelişmesiyle görüşmüştür ki sinema tüm imkânları içine alarak kümülatif bir şekilde yoluna devam etmiştir. Buna rağmen sinemanın ilk yıllarındaki sinema pratiğinin saf sinema anlayışına uygun bir çizgide olduğu ve ilk yıllardaki bu pratiklerin saf sinemanın ilk ve köklü örnekleri olduğu düşüncesi de yanlış olmayacaktır. Ayrıca bu düşünce şu soruyu sormamızı da zorunlu kılar; acaba sinema gelişim gösterdikçe aynı zamanda saflıktan uzaklaşmakta mıdır? Bunun dışında Rudolf Arnheim gibi sinemanın ilk kuramcıları da “... çok boyutlu aracın kontrol etmekte yetersiz kalan renkli film haz veren 'renk uyumlarının' ötesine 
geçememiştir" (2010: 12) ifadeleriyle ses ve renk gibi gelişmeleri eleştirmişlerdir. Ancak daha sonra bu gelişmeler sinemanın önemli ifade araçları olarak yerini almıştır ve tarih ilerledikçe mecra yeni ifade araçlarını içine alarak yoluna devam edecektir.

Son olarak Balazs'ın şu sözleri mecranın kendi özelliklerini başka değişle kendi ifade imkânını dışlayan bir sinema anlayışını -saf sinemanın dışında kalan sinema anlayışı- özetler niteliktedir;

"Edebi yanı uydurulmuş, görüntüleri hareketli illüstrasyonları art arda sıralanmasından ibaret, içeriği zaten başlıkta verili bir metinden oluşsan filmler vardır. Asası teşkil eden dışsal ve içsel olayların her birini başlıktan çıkarabiliriz ve sonra, olay örgüsü kendi ifade aracı ile gelişemeden, söz konusu olaylarn görmeye başlanz. Bu tür filmler kötüdür, çünkü salt olarak filmle ifade edebilecek olan hiçbir şeye sahip değildirler. (2013: 38)

Bela Balazs'ın düşünlerinden hareketle ilerlediğimizde ulaştı̆̆ımız nokta sinemanın özünün daha çok veya en nihayetinde görüntü- imajlara dayandığıdır. Her ne kadar diğer ifade araçları da sinema sanatı için çok önemli bir konumda olsa da görüntü bunun temelini oluşturmaktadır. Sinema sanatı göz önüne alındığında bu hareketli bir görüntüdür.

\section{Siegfried Kracauer'ın 'Sinematik Olan’ Kavramından Saf Sinemaya}

Sinematik kavramı kelime anlamı olarak sinemaya özgü olan, sinema özelliği taşıyan ve sinemayla ilgili anlamlarına gelen bir kelime olarak karşımıza çıkar. Kracauer'da zaten 'sinematik olan'la sinemaya özgü olan şeyi işaret etmeye çalışmıştır. Bu anlamda Kracauer'un bu kavramsallaştırması, yukarıda Bela Balazs'ın fikirlerinden yola çıkarak saf sinemaya ulaşmaya çalıştığımız yola benzerlik göstermektedir. Bu anlamda Bela Balazs'ın sinema için söylediği yeri doldurulamaz ifade biçimi sözü Kracauer'da sinematik olan olarak karşılık bulur. Zaten Kracauer'un kuramını oluşturma yolculuğuna Balazs'ın açtığı yoldan başladığı düşünülürse bu anlaşılabilir bir durumdur.

Kracauer'a göre film fiziksel varoluşu tesis ederken bunu fotoğraftan farklı olarak iki şekilde yapar. Bunlar varlığı zaman içinde evrilirken sunması ve sinemanın olanakları ile yapmasıdır (2015: 124). Kracauer'a göre bu varlığın zaman içinde evrilirkenki durumu sinemada iki şekilde görülür. Bunlardan biri 'kaydetme' bir diğeri ise 'ifşa etme işlevi'dir. Bunlardan kaydetme işlevi olağan ve kolay olanken ifşa etme işleminde sinema tekniklerinin müdahalesi olmadan gerçekleşmesi güçtür. (124) İfşa etmenin ise üç işlevi vardır: normalde görünmeyen şeyler, bilinci afallatan fenomenler ve gerçekliğin özel tarzlarıdır (Kracauer, 2015: 130-149). Burada özellikle 'kaydetme' ve 'ifşa etme' olarak adlandırılan işlevler saf sinema arayışında sinemanın özüne yapılan karanlık yolculukta yol gösterici bir ışık olarak karşımıza çıkmaktadır. Çünkü kaydetme işlevi fiziksel varoluşun kaydedilmesi anlamına gelir. Yani bizim dışımızdaki hayatın, görüntülerin kayıt altına alınması. Bu sinema mecrasının temel medyumu olan kameranın ve doğal olarak sinemanın en temel özelliğidir. Kaydetme işlevi kayda alınmış ham görüntülere karşılık gelir. Buna ifşa etme işlevi de eklendiğinde sinematik operasyonlar da dâhil olur ve gündelik hayatın içinde fark edemediğimiz, kaçırdığımız nüanslar fark edilebilir bir hale gelir. Ayrıca bahsi geçen görüntüler bu şekilde fiziksel gerçeklik içindeki anlamlarından çıkarak farklı bir anlama bürünür ve seyirciye bir şeyleri ifşa etmeye başlarlar. Başka bir değişle görüntülerin kendisi anlam üretir hale gelir. Bu iki işlevden ilkinde görüntünün kayıt altına alınması durumu 
varken ikincisinde kayıt altında alınan görüntülerin bir şeyler anlatması durumu ön plana çıkar. Bu da aslında sinematik yaklaşım ile birlikte bize Kracauer tarafından sinema özüne açılan bir pencere sunmaktadır.

Bunların yanı sıra Kracauer'nun Bela Balazs'ın görüşüyle yakınlık gösteren şu sözleri yine sadece sinemanın olanakları ile sinema yapmak anlamını taşıyan saf sinemanın sınırlarını çizmek adına bize fikir vermektedir; "filmler temel özellikleri üzerinde yükseliyorsa estetik açıdan meşruiyet iddiasında bulunabilir" (Kracauer, 2015: 119). Bu görüş bizi yukarıda Balazs'dan hareketle tartışılan vazgeçilmez ifade aracı en nihayetinde görüntüyse bu bize yine belgeselvari bir düzleme mi götürür? sorusuyla buluşturur. Ancak bu yaklaşım ve işlevlerin yanı sıra Kracauer filmin en genel ve en olmazsa olmaz özelliklerinden birinin de kurgu olduğunu ifade eder (2015: 108). O halde iki görüş harmanlanırsa saf sinema tartışmasında ilk olarak ortaya atılan ve sinemanın ilk yıllarına benzetilen hayatın düz bir kaydı geçerliliğini yitirecek ve yine saf görüntülere dayalı ancak aynı zamanda içinde sinematik kurgu öğesinin de bulunduğu kurgusal bir yapı olarak da bakılabileceği görülecektir. Görüldüğü gibi saf sinema kavramı bu adımlarla faklı açılardan bakılabilen bir kavram olarak çıkar. Ancak iki düşünürden hareketle ortaklaşılan bir nokta gözden kaçırılmamalıdır: film kurgusal veya belgeselvari de olsa ikisinde de görüntü imajlar merkezi bir yer oynar. Kracauer'nun bu düşüncesini destekler nitelikte Rudolf Arnheim'da Sanat Olarak Sinema eserini tanımlamak için aynı kitapta "Bu kısacık inceleme, biçim, içerik ve işlevlerindeki tüm değişikliklere rağmen filmlerin en hakiki biçimde etkili olmayı hala görsel ortamın temel özelliklerine dayanarak başardıklarını, halen okunuyor olmasıyla kanıtlıyor gibidir" (Arnheim, 2010: 7) ifadelerine yer verir. Arnheim'ın bu düşünceleri sadece eseri hakkında bilgilere yer veriyor gibi görünse de içeriğine dikkatli bakıldığında sinemadaki tüm değişikliklere rağmen hala filmlerin etkili olabilmesini tıpkı Kracauer'da olduğu gibi mecranın temel özelliklerine dayanması olarak tanımlamaktadır.

Film Teorisi eserinde Kracauer sinematik yaklaşım kavramını sinemanın diğer tüm araçlarını kullanarak tartışmıştır. Tüm araçların hangi kullanımının mecraya uygun yani sinematik olduğu konusunda kapsamlı bir çalışma yürütmüştür. Bunlar arasında diyalog, ses, müzik, oyunculuk, hikâye ve olay örgüsü gibi sinemayla iç içe geçmiş birçok ifade aracı vardır. Diyalog örneği üzerinden başarılı ve sinematik bir kullanımı ele alacak olursak "bu konuda başanlı girişimlerin ortak bir noktası vardır: görsellerin hakkın vermek için diyaloğun rolünü azaltmak" (Kracauer, 2015:209). Diyalog ancak bu şekilde görselleri öne çıarmak adına, görsellerin bir adım ardında olacak şekilde kullanılması şartıyla sinematik olur. Dolayısıyla diyalog görüntülerin önüne geçerek baskın bir karaktere dönüşmemelidir. Bu durum diğer tüm araçlar için de geçerlidir. Eğer sesin, müziğin, hikâyenin ve olay örgüsünün sinematik bir kullanımından bahsedeceksek bu araçların kullanımının görüntünün önüne geçmemesi, onu destekleyen, besleyen bir unsur olarak kullanılması gerekir. Bu durum saf sinema içinde geçerlidir. Oyunculuk ise tiyatrallikten ne kadar uzak olursa o kadar sinemaya özgü yani sinematik olur (Kracauer, 2015: 195-210- 363). Çünkü sinema ve tiyatro sanatları ifade biçimleri açısından farklı mecralardır. Dolayısıyla oyunculuk biçimleri de bu bağlamda farklılık gösterecektir. Tiyatro sahnesinin doğası gereği oyuncu sesini, jest ve mimiklerini 'abartılı' kullanmak zorundadır. Çünkü seyircinin sahneye olan konumu sabittir ve oyuncu sesini ve beden hareketlerini tüm seyirciye ulaştırmak zorundadır. Oysa sinema oyunculuğunda kamera ve kameranın hareketleri (yakın çekim, ağır çekim vb.) ve sesin kayıt altına alınarak seyirciye ulaştırılabilmesi özelliklerinden ötürü tiyatrodakine benzer bir 
tarz izlenmesi gerekmez. Hatta bir sinema filminde gördüğümüz tiyatrovari bir oyuncuk tarzı tam da bu sebeplerden dolayı sinematik değildir. Bu konu sinemanın ortaya çıkışından bu yana sinema ve tiyatro sanatları sürekli karşılaştırılma yoluna gidilerek zaten tartışılmıştır. Özellikle sinemanın ilk kuramcıları bu konuyu sürekli tartışmışlardır ve sinemanın tiyatrodan tamamen farklı, kendi başına bir sanat olduğu ifade etmişlerdir. Ancak sinemadan çok önceleri ortaya çıkmış bir sanat olan tiyatronun sinemayı etkilemediği veya sinemanın bazı özelikle de ilk örneklerinde tiyatronun etkilerinin görülmediğini söylemek son derece yanlış olacaktır. Sinema ilk yıllarında tiyatrodan etkilendiği gibi tiyatro da günümüzde büyük gelişimler kaydetmiş sinemadan etkilenmektedir. Konuya Kracauer'nun sinematik oyunculuk düşüncesi tarafından bakacak olursak sinema oyuncuları izleyiciyi, karakterin yaşadığı olayın maddi varoluşun bir parçasında yaşanıyormuş izlenimi yarattığ1 taktirde yani seyirciyi bu şekilde etkilediği taktirde gerçekten sinematik olabileceğini savunur (2015: 195).

Kracauer'nun sinematik yaklaşımı ile kaydetme ve ifşa etme işlevleri ve bunun dışındaki film teorisini oluşturan tüm fikirlerinin ortaklaştığı bir nokta vardır: Görüntülerin merkezi konumu. Görseller veya görüntüler sinemanın diğer tüm temel özelliklerinin üzerinde tutulmuş ve mecranın temeline konumlandırılmıştır. Bu görüşler aslında genel bir ifade olan 'sinema görsel bir sanattır' ifadesiyle de paralellik gösterir. Buradan hareketle sinemanın özüne yapılan bu yolculukta Balazs'dan sonra Kracauer'da da bu özün görüntü imajlar olduğu sonucuna ulaşllabilir. Bu ses, diyalog, müzik, hikâye ve oyunculuk araçlarının hepsinin görüntü imajları destekleyecek şekilde kullanılmasından açıça ortaya çıkmaktadır. Bu durumda ortaya çıkan görüşler saf sinemayla ilişkilendirildiğinde, bu düşüncelerin aynı zamanda saf sinemanın çerçevesini de belirlediği ortaya çıkmaktadır. Tüm bunların dışında Kracauer'un fiziksel varoluş, maddi varoluş veya fiziksel gerçeklik olarak tanımladığı gerçek hayat vurgusu atlanmamalıdır. Kracauer bu kavramlarla sürekli olarak gerçekliği ve filmlerin gerçeklikle olan ilişkisini vurgulamakta ve sinemanın tüm araçlarının gerçeklikle bağının korumasına azami özen gösterilmesini dile getirmektedir. Bu bağlamda Kracauer'dan hareketle filmlerin geçeklikle bağını koruduğu sürece saf kalabileceği varsayımı çıkarılabilmektedir. Kracauer'un kuramının gerçeklikle olan bu bağı Film Teorisi kitabının yazıldığı dönemle de yakından ilgilidir. Çünkü kitabın yazıldığı 2. Dünya Savaşı sonrası dönem, İtalyan Yeni Gerçekçiliği ve Fransız Yeni Dalgası gibi sinema alanında yeni akımların ortaya çıktığı bir döneme karşılık gelmektedir (Özarslan, 2015: 218).

\section{Gilles Deleuze'ün Hareket ve Zaman İmge Kavramlarında Sinemanın Özünü Aramak}

Gilles Deleuze'ün izinden özellikle hareket imge ve zaman imge kavramları üzerinden sinemanın özüne bir yolculukla saf sinemayı tartışmaya açmak için Deleuze'ün sinemanın temelini oluşturan bu iki kavramının genel tanımlarının dişında özgün bir değerlendirmesi yoluna gidilmiştir. Bu bağlamda hareket ve zaman imge kavramları sürekli yapılan tanımlamaların dışında görüntülerin farklı şekillerde kullanımları olarak değerlendirilecektir. Bu bağlamda hareket imge kavramı görüntülerin veya görüntü bloklarının mantıksal, zaman-mekân bütünlüğüne sahip ve neden sonuç ilişkisi içinde bir araya gelmesi anlamı taşır. Görüntülerin bu şekilde bir araya gelmesi belli bir sinema anlayışına karşılık gelmektedir. Bu karşılık kendini Hollywood veya klasik anlatının hâkim olduğu tüm filmlerde bulmaktadır. Zaman imge ise hareket imgenin aksine görüntülerin 
neden sonuç bağlantısının dışında daha kristalize, muğlak bir şekilde titreşimler yaratarak bir araya gelmesi anlamı taşır. Bu iki yorumdan çıkarılacak temel nokta iki imge türü için de kavramın kendisinden de çok iyi anlaşıldığı gibi görüntünün yine merkezi bir şekilde konumlandırılmasıdır. Başka bir değişle Deleuze'ün sinemanın en temeline yerleştirdiği hareket imge ve zaman imge kavramları, merkezi konuma imgeleri yani görüntüleri yerleştirmiştir. Buradan hareketle Deleuze tarafından sinemanın özünün görüntü merkezli bir anlayış olduğunu ifade etmek olası görünmektedir. Bu noktada Deleuze ve onun sinemaya ait düşüncelerinin saf sinemayla olan ilişkisi ortaya çıkmaktadır.

Bu görüş Deleuze'ün ifadelerinde de karşılık bulur. Deleuze sinemanın hareket ve zaman blokları ürettiğini ifade eder. Burada harekete ve zamana dayanan imgeler ve görüntülerin mecranın özünü oluşturduğu anlamı yatar. Deleuze bunu kendi sorduğu soruya verdiği cevapla net bir şekilde ortaya koymaktadır;

"Ben felsefe yaptığımı söylüyorum, yani kavramlar icat etmeye çalışıyorum. Peki sorsaydim, siz sinema yapanlar, siz ne yapiyorsunuz? Siz, sinema yapanlar kavramlar icat etmiyorsunuz -sizin işiniz değil bu - ; siz, hareket- süre bloklarn yaratıyorsunuz. Başka bir değişle, eğer hareket- süre bloklan imal ediyorsanız sinema yaptığınızdan söz edilebilir ancak"(Deleuze, 2003: 20-21).

Sinemanın kendine has ifade biçimini yine mecranın özü şekillendirmektedir. Bu farklı mecralar veya disiplinler için faklı medyumlar olabilir. Bu anlamda sinemanın özü Deleuze'den harekete ve zamana dayalı bloklar, görüntülerdir. Burada önemli olan nokta zaten her mecra veya disiplinde olan hikâye anlatmak değildir. Çünkü hepsi zaten bizlere bir hikâye anlatmaktadır. Tek fark felsefe hikâyesini kavramlar yoluyla, resim çizgi bloklarıyla, müzik nota bloklarıla ve bilim ise fonksiyonlar yoluyla hikâyesini anlatır. Sinema ise bunların hepsinden faklı olarak duyumlar yoluyla hareket- süre bloklarıyla hikâyesini anlatır (Deleuze, 2003: 21). Benzer şekilde saf sinemanın izlerinin aranacağı bir yer olarak karşımıza çıkan yönetmen Robert Bresson'nun da sinemanın diğer sanatlarla ilişkisi konusundaki "sinematografin doğrusu, tiyatronun, romanın ya da resmin doğrusuyla bir olamaz. (Sinematografin kendi imkânlarıyla yakaladığı şey, tiyatronun, romanın ya da resmin kendi imkânlarıla yakaladı̆̆ı şeyle bir olamaz.)" (Bresson, 2012: 18) ifadeleri Deleuze ile paralellik gösterir. Bunlar sinemanın özüne yapılan bir yolculukla saf sinemayı tartışırken kullanılan 'sinemanın kendi araçları ile sinema yapmak', 'yeri doldurulamaz ifade aracı' ve 'mecranın temel özellikleri' ifadeleri gibi bizi bir yol göstermektedir. Bu yol sinemanın özüne giden yolun Kracauer ve Balazs' da olduğu gibi görüntüye dayandığını farklı bir yolla söyler. Ama ortak nokta sinemanın diğer sanat ve disiplinlerden farklı yollarla kendini ifade ettiğidir. Deleuze bir fikrin resimde, romanda, felsefede veya bilimin içinde olabileceği gibi her alanda var olduğunu fakat boşlukta, genel geçer bir yapısının olamayacağını ve ancak bir tekniğin içinde kendini var edebileceğini söyler. Bu anlamda fikirler mecralarının ifade tarzlarından katiyen ayırt edilememektedir. Başka bir değişle fikir kendi başına var olamaz ancak felsefenin içinde bir fikir veya sinemanın içinde bir fikir ayakları üzerinde durabilir. (Deleuze: 2003: 18) Burada hiyerarşik olmayan bir ilişki söz konusudur. Sinema bu anlamda ne felsefenin kavramlarına, ne bilimin fonksiyonlarına ihtiyaç duyar. Sinema kendi hikâyesini kendi alanı ve yine kendine ait ifade araçlarını kullanarak anlatır (Öztürk, 2018: 127). Bu durum farklı disiplinlerde olduğu gibi farklı sanatlar için de geçerlidir. Bir filmde gerçekliğin ve yalınlığın 
yanı sıra bahsedilen kendi ifade araçlarını kullanma noktasına ne kadar bağlı kalırsa o kadar saf sinemaya yaklaşmış olur.

Bu bağlamda Deleuze'e göre her sanatın ve disiplinin kendi ifade biçimi olduğu gibi sinemanın da kendine has bir ifade ve üretim biçimi vardır. Bu hareket ve süre bloklarının yani hareket ve zaman imgelerin üretilmesi yoluyla olur. Deleuze'e göre hareket imgenin bu üretimi temelde iki şekilde olur. Bunlardan biri kamera hareketi ikincisi ise montajdır. "Montaj, uyuşumlarla, kesmelerle, uyuşumsuzluklarla bütünün belirlenmesidir"(Deleuze, 2014: 47). Deleuze'ün sinema anlayışını oluşturan bu iki temel kavram bize bu anlamda bir yol gösterir o da harekete ve zamana dayanan görüntüler, imajlardır. Böylelikle Balazs'dan başlayıp Kracauer ile devam eden ve Deleuze'de sonuna yaklaşılan sinema özüne yapılan yolcukta görüntünün merkezi konumunun bir kez daha ortaya çıktığı görülmektedir. Ayrıca Deleuze'ün sinema felsefesi üzerine tüm bu fikirlerini bir sinema teorisinden öte düşüncenin çağımızdaki bu yeni sunumunu anlama ve anlamlandırma çabasındaki felsefi bir yolculuk, oluş halindeki felsefi bir çalışma olarak görmek daha doğru olacaktır (Sütcü, 2015: 14).

\section{Dogma 95 Bir Saf Sinema Çabası Olarak Görülebilir Mi ?}

Dogma 95 Paris'te sinemanın 100. yılının kutlandığı bir günde Lars von Trier ve arkadaşları Thomas Vinterberg, Kristian Levring ve Søren Kragh-Jacobsen tarafından bir manifesto ile ortaya çıkan sinema akımdır. Dogma 95 sinemanın 1960'larda öldüğünü Fransız Yeni Dalga' nın bunu tekrar yeşertmeye çalıştığını söyler. Bunu kendilerine görev edinseler de belli bir ilerleme sağlamasının dışında onlar da bu konuda başarılı olamamıştır. Artık sinema alanında çok büyük ve etkili akımlardan sonra bu tür bir oluşumun bir daha ortaya çıkmasının beklenmediği bir dönemde Dogma 95 sinemaya bir protesto halinde giriş yapmıştır. Dogma 95 tüm bunları bir manifesto ile yapmıştır. Akım bu manifestodaki kurallara uymayı gerektirmektedir. Kurallar genel olarak günümüz sinema anlayışına bir tepki olarak ortaya çıkmış ve yeni bir sinema anlayışı getirmeye çalışmıştır. Akımın başlıca yapıtları arasında Lars von Trier'in Riget (Krallık, 1994), Breking The Waves (Dalgaları Aşmak, 1996), Idioterne (Geri Zekahlar, 1998) ve Thomas Vinterberg'in Festen (Şölen, 1998) gösterilebilmektedir.

Dogma 95 temelde illüzyon sineması olarak adlandırılan sinema anlayışına karşı bir duruş olarak ortaya çıkmıştır. Yalnız burada illüzyon sineması ile kurgusal sinema anlayışını dile getirmez. Dogma 95'in ortaya koyduğu filmlerde kurgusal bir yapıya sahiptir ancak Dogma 95’ın buradaki farkı müzik, efekt, yapay aksiyon gibi araçlara izleyiciyi yönlendirdiği gerekçesiyle karşı çıkmasıdır. (Topçu, 2013: 208) Dogma 95'in burada karşı çıktığ1 sinema pratiğinin Hollywood tarzı üretimler olduğu açıtır. Dogmanın manifestosundaki kurallar üzerinden giderek bu akımın saf sinema anlayışına ne kadar uyduğunu tartışmak daha yerinde olacaktır;

1-Çekimler stüdyo dışında yapılmalıdır. Sahne donanımı ve setler içeri taşınmamalıdır. (Hikâye özel bir sahne donanımı gerektiriyorsa, stüdyo dişında bu donanıma uygun bir mekân seçilmelidir.)

2-Ses, kesinlikle görüntülerden ayrı olarak üretilmemelidir ya da tersi. (Sahne içinde üretiliyor olmadığı sürece müzik kullanılmamalıdır.) 
3-Kamera, elde taşınıyor olmalıdır. Elde taşınan kamera ile elde edilecek hareketlilik ya da hareketsizlikler serbesttir. (Film, kameranın durduğu yerde çekilmemeli; kamera filmin olduğu yerde olmalıdır.)

4-Film, renkli olmalıdır. Özel ışıklandırma kullanılamaz. (Eğer çekilecek olan sahnede filmin pozlandırması için çok az bir ışık söz konusuysa, sahne kesilmeli ya da tek bir lamba kameraya iliştirilmelidir.)

5. Optik numaralar ve filtreler kesinlikle yasaktır.

6-Film, gelişigüzel aksiyon içermemelidir. (Öldürme, silahlar, vs. bulunmamalıdır.)

7-Zamansal ve coğrafi yabancılaştırmalar yasaktır. (Kısaca film, şimdi ve burada geçmelidir.)

8-Tür filmleri kabul edilemez.

9-Film formatı $35 \mathrm{~mm}$ olmalıdır.

10-Yönetmen, jenerikte belirtilmemelidir. ( Topçu, 2013: 221)

Ayrıca yönetmen olarak, kişisel üsluptan kaçınacağıma ant içerim. Ben artık bir sanatçı değilim. Anları bütünden daha önemli gördüğüm gibi, bir 'eser' yaratmaktan kaçınacağıma ant içerim. En büyük hedefim karakterlerimden ve ortamdan gerçeği açıkça çıkarmak olacaktır. Tüm bunları elimden geldiğince, iyi üslup ve estetik kaygılar pahasına yapacağıma ant içerim.

Dogma 95 akımı bu kurallara uymayı gerektirmektedir. Bu kurallar dâhilinde katılmak isteyenler bu kurallara sadık kalacağına dair yemin ederler. Bu kurallara baktığımızda çekimlerin stüdyo dışı ortamlarda geçmesi, özel 1şıklandırma kullanılması istenmemesi, optik numara ve filtrelerin kullanılmaması ve filmin gelişigüzel aksiyon içermemesi gibi kurallardan yola çıkılırsa aslında Dogma 95' in saf sinemaya ulaşma yolunda yol gösterici bir yanı olduğu kuşkusuzdur. Örneğin stüdyo dışında yapılan çekimler sinemanın gerçeklikle ilgisini arttıran ve bizi daha az illüzyonvari bir dünyaya maruz bırakan bir etkiye sahiptir. Gelişigüzel aksiyon içermemesi maddesi bize Hollywood'un hareketli kurguya dayalı ve filme herhangi bir yabancılaşma yaşamadı̆̆ımız klasik filmlerini çağrıştırır. Bu filmlerin saf sinema anlayışına tam tersi bir istikamette durduğu düşünülürse bu maddenin saf sinema arayışında en etkili maddelerden biri olduğu söylenebilir. Özel 1şıklandırma kullanılması yerine daha çok doğal 1şıkların kullanılması kuralı ve optik numaralar ve filtrelerin kullanılmaması yine bizi saf sinemanın sınırlarına taşıyan bir unsur olarak görülebilir. Ancak burada bağlam yukarıda Bela Balazs tarafından baktığımız bağlamdan farklıdır. Dogma 95 Manifestosu'nda sayılan kurallar sinemanın illüzyonvari yapısından bizi uzaklaştırması ve gerçeklikle bağının korunması anlamında bizi saf sinemaya götürebilmektedir.

Dogma'nın yukarıda ele aldığımız kuralları dışında kalanlar ise saf sinema olmanın dışında daha çok bir farklılık yaratmak adına konulan kurallar gibi görünmektedir. Örnek verecek olursak; yönetmenin isminin jenerikte geçmemesi, zamansal ve coğrafi yabancılaşmayı yasaklaması gibi maddeler saf sinema arayışından oldukça uzaktır. Çünkü saf sinema sinemanın özü, sinemanın kendine has ifade araçları, medyumları ile ilgilidir. Bahsi geçen maddeler ise bu konulara değinmekten son derece uzaktır. Ancak Dogmacılar tarafından da vurgulandığ1 gibi, kuralların biçim yaratan yaratıcı öğeler olduğu ve bu kuralları asıl odak noktası haline getirilmemesi gerektiği vurgulanmıştır. Kurallara sinema 
aracını ağırlaştıran ve aynı tür filmlerin ortaya çıkmasına engel olup, iyi bir öykü ve oyunculuktan meydana gelen saf bir sinema anlayışı ile gerçeğin peşinden koşmak olarak da bakmak mümkündür (Topçu, 2013: 212). Ancak Dogma akımı ne burada bahsedildiği gibi büsbütün bir saf sinema arayışı ne de saf sinema arayışının tamamen dışında bir oluşum olarak görülebilir Bununla birlikte saf sinema kavramının sınırlarını çizerken büyük katkılar sağlayacağ1 açıktır.

\section{Yönetmen Tayfun Pirselimoğlu'nun Saf Sinemaya Bakışı}

Saf sinemanın sınırlarını çizmek, onu sıvı bir halden katı bir hale getirerek elle tutulur bir özellik kazandırmak için nasıl ki ilk kuramcılar ve sinema akımları gibi kuramsal unsurlara başvurmak gerekli ve zorunlu bir yönelimse aynı şekilde bu işi icra eden yönetmenlerin fikirleri de bizim için önem arz etmeli ve başvurulması gereken bir kaynak olarak anlaşılmalıdır. Bu anlamda örnek film olarak seçilen Yol Kenarı filminin yönetmeni ile saf sinema konusunda 2018'in Kasım ayında gerçekleştirilen görüşmeden bazı anekdotlar aktarilacaktır.

Tayfun Pirselimoğlu'nun konu hakkındaki ifadeleri şu şekilde; "Bence saf sinema 'numara yapmayan' anlamına geliyor; yani izleyici ile ilişkisini bir illüzyon gösterisi haline getirmemesini kastediyorum". Yönetmenin buradaki ifadelerine bakıldığında saf sinemaya bakışımızda bize yeni bir yol göstermektedir. Saf sinema gerek biçimsel özellikleri gerekse içeriksel özellikleri ile yönetmenin değimiyle 'numara yapmayan' bir şeklide kendini var etmelidir. Örneğin ana akım filmlerin içerik ve tekniğinin biçimlenmesi gözler önüne getirilirse bu ayrım daha iyi anlaşılacaktır. Hollywood sineması veya klasik anlatı filmleri seyircinin, sinema salonuna girdiği ve çıktığı zaman arasındaki dilimde aksiyon ve hızlı bir kurguyla kendinden geçmesine hatta düşünce durumundan çıkmasına sebep olmaktadır. İşte illüzyon tam da burada gerçekleşmektedir. Seyirci düşünce durumunun dişına çıkmış ve sadece haz amaçlı bir eylem içinde hapsolmuştur. Zaten sinema salonundan çıtı̆̆ında zamanın nasıl geçtiğini anlamadığı bir durumun yanı sıra kendini rahatlamış bir şekilde bulmaktadır. Bu alana karşılık gelen filmler saf sinemanın dışında konumlanmaktadır. Bunun tam tersinde konumlanan ve sanat filmi olarak tanımlanan film örneklerinde ise seyirci film sırasında sürekli sorular soran bir düşünce dalgalanması yaşar. Sinema salonundan çıktığında düşünceli, yorgun ve 'huzursuz' dur. Yönetmen Tayfun Pirselimoğlu'nun bu konudaki yaklaşımı anlatılanları özetler niteliktedir: "Ben her anlamda olağanın peşindeyim. Hikâyenin kendisi olağanüstü olabilir ama bunun aktarımı bir illüzyon yaratma biçimi olmamalı". Buradan hareketle zaten saf sinemanın saflığı da görüntünün merkezi konumun ve gerçeklikle bağının dışında bu 'olağan' durumdan gelmektedir. Bu sinema anlayışında illüzyon, hız, katarsis dışarıda bırakılmalı ve görüntünün egemenliği dışında, 'olağan', sadelik, minimalizm ve yabancılaşma unsurlarına kapı açılmalıdır. Başka bir değişle 'sinema araçlarının tutumluluğu' (Tarkovski, 2018: 169) gözetilmelidir. Bu olağanlık, sadelik veya ifade araçlarının tutumluluğu kavramlarını yönetmen şu şekilde ifade etmektedir: "Görüntü ve ses tasarımından, müzik kullanımına, oyunculuk performanslarma kadar geniş bir yelpazede 'olağanın' peşindeyim. Hikâyenin kendisi 'olağan üstü' olabilir ama bunun aktarım ve anlatımı bir illüzyon yaratma biçiminde olmamalı. Yol Kenar da diğer filmlerim de bu anlayışın ürünleridir diyebilirim". 
Görüldüğü gibi saf sinemanın gerçeklikle bağının korunması ve görüntülere dayanması özelliğinin yanına son olarak 'illüzyon' yapmayan daha çok gerçeğe ve olağana hizmet eden bir özellikte eklenebilmektedir. Bu noktaya saf sinemanın bağımsız- düşence sineması içinde bir yerde konumlandığı ve burada aranması gerektiğine dair bir iz olarak bakılabilmektedir.

\section{Saf Sinemaya Bir Örnek Olarak Yol Kenarı Filmi}

Yol Kenarı Tayfun Pirselimoğlu'nun yazıp yönettiği 2017 yılı yapımı dram-gerilim türündeki Türk filmidir. Film bir tarafında denizin diğer tarafı ise tehlikeli bir ormanın olduğu bir sahil kasabasında geçmektedir. Kasabada uzun süredir yaşanan tuhaf olaylar kasabalılarca kıyamet alameti olarak değerlendirilmektedir. Bu olaylar sahile demirlemiş bir gemi, çıkış sebebi anlaşılmayan yangınlar, anlamsız cinayetler, nerden geldiği belli olmayan garip ses ve bir türlü gelmeyen bir devlet büyüğü şeklinde siralanmaktır. Daha sonra kasabaya iş bulmak için gelen bir gence tüm olaylar ışığında kasabalılar tarafından çok farklı anlamlar yüklenir. İsmi ve nerden geldiği bilinmeyen genç kasabalılarca tüm bu kıyamet alametlerinden onları kurtaracak mehdi olarak görülür. Sırtında tıpkı İslam dininde mehdinin işareti olan bir iz vardır. Bu seyirciye gösterilmez ancak tüm kasabalı tarafından konuşlan bir olay haline gelmiştir. Film kasabalının gençten kurtuluş beklediği, gencin ise tüm bunlara anlam vermeye çalışması ile ilerler. Filmin sonuna doğru kasabalıyı tedirgin eden gemi kaybolur. Denizden gelen ve öldürülen adam dirilir. Tek gözünün takma olması sebebiyle yine İslam dinindeki Deccal'e benzetilebilecek karakter kasabaya iş aramak için gelen ve Mehdi olduğuna inanılan karakter tarafından öldürülür. Bu anlamda filmin çok katmanlı bir yapısı olduğu söylenilebilir. Filmin sonu izleyen kişiye göre farklı yorumlara açıktır.

Filmde kasabanın adı, nerde olduğu ve kasabada yaşayan insanların isimleri bilinmemektedir. Bu anlamada film zamansız ve mekânsız bir yapıya sahiptir. Ayrıca kurulan bu yapı aynı zamanda tam tersi olarak her zamanda ve mekânda gerçekleşebilir izlenimi verir. Film bir kiyamet filmi olarak yorumlanmaktadır. Ancak kıyametin ileri bir zamanda yaşanılacağı düşünülen kıyamet mi yoksa daha önceden yaşanılmış kıyamet olarak adlandırılan bir zaman veya dönem mi olduğu veya şu an içinde yaşadığımız zamanın bizzat kıyametin kendisi mi olduğu konusu film boyunca sürekli sorgulanmaktadır. Özellikle şu an içinde yaşadığımız gündelik yaşama atıfta bulunması yani 'artık insanlık olarak dünyada yaşanan bunca kötü olayla gerçek dünyada kıyameti yaşamaktayızdır' düşüncesi önem arz etmektedir. Tüm bunlar tam da bu zamansızlık ve mekânsızlık durumunun filme kattığı bir zenginliktir. Film aslında anlamsızlıklar üzerine kurulu, anlamsızlığın anlamlı bir hale geldiği bir evren kurar. Karakterlerin davranışları, diyalogları, ilişkileri, mekân kullanımlarının hepsi izleyiciyi bir anlamsızlığa sürükler. Filmde anlamsızlığın kendisi bir anlam olarak karşımıza çıkmaktadır. Belki tüm bunların sonucunda görüntüler daha fazla anlam kazanmaya başlar.

Yol Kenarı filmi zamansızlığının bir parçası olarak günümüz dünyası ve içinde yaşadığımız ülkeye dair de bazı saptamalar ve eleştirilerde bulunur. Kadın cinayetleri, çocuk tecavüzleri, sır ölümler, kitapların yakılması gibi konular filmde ele alınmaktadır. Filmin bu gibi konulara yer vermesi bakımdan bir tarafıyla da politik bir yanının olduğunu söylemek 
önemlidir. Filmde mekânların, diyalogların, müziğin minimal şekilde kullanılması başka bir değişle film boyunca kendini belli eden sadelik hali bizi görüntüler ve buradan hareketle saf sinema üzerine düşünmeye sürüklemektedir. Bu durum zaten görüntülerle bir şeyler anlatma derdinde olan filmi beslemektedir. Filmde siyah-beyaz renk tercihi bile bizi sezgisel bir anlamda sinemanın ilk yıllarındaki o saflığa götürür. Yol Kenarı filminin saf sinema ile bağının kurulması noktasına gelecek olursak öncelikle filmin Bela Balazs, Kracauer ve Deleuze' den hareketle vardığımız görüntü-imaj temelli anlayışa uyumlu bir çizgide ilerlediği görülmektedir. Filmin imajlar üzerine kurulu bir yapısı vardır ve bu yapı film boyunca devam etmektedir. Bunun dışında ifade araçlarının tutumlu kullanılması durumu da filmi diğer filmlerden ayırır ve bize saf sinemaya ait bir dünya sunar.

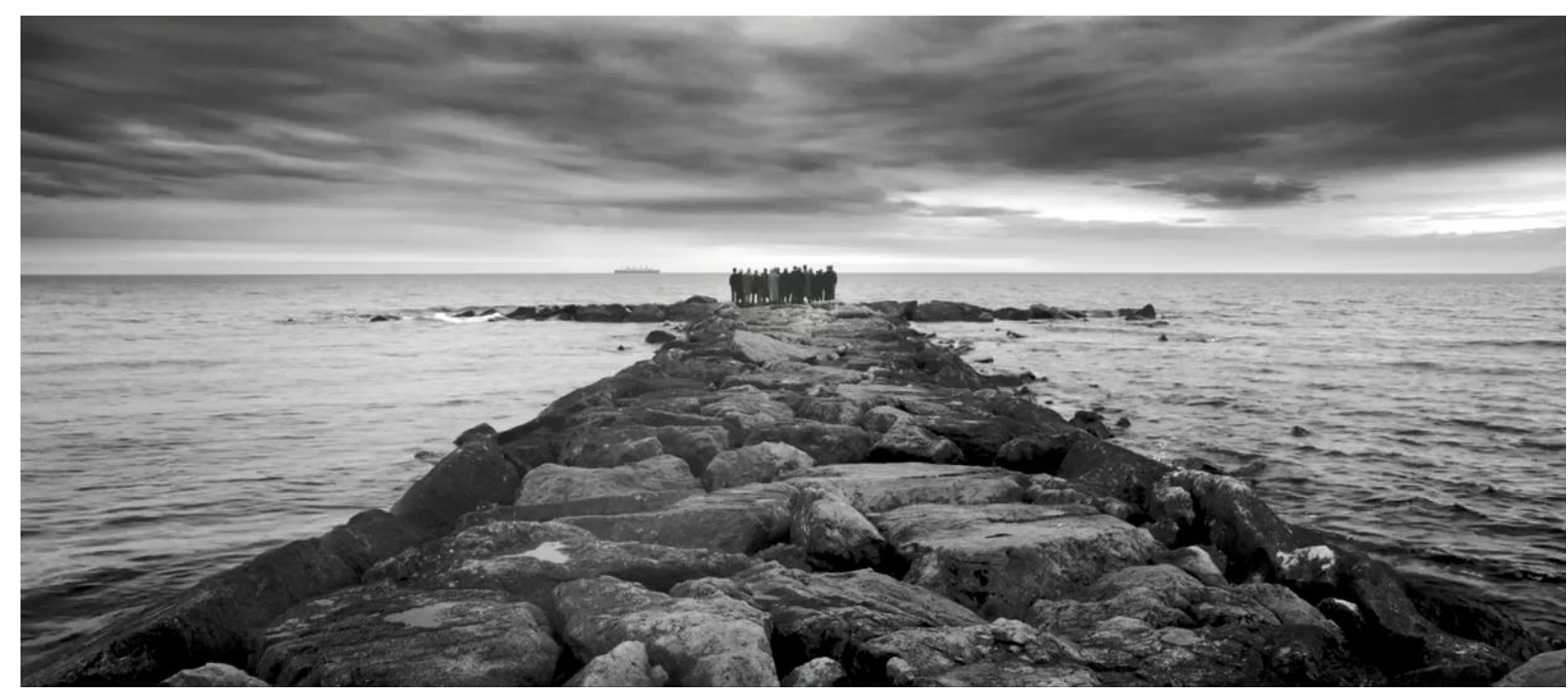

Görsel 1 : Kasabalı açıtaki gemiye bakmaktadır.

Film kasabalının taştan rıhtımın ucunda toplanarak uzaktaki gemiye baktıkları sahneyle açılır. Kasabalı meraklı bir şeklide ve hiç konuşmadan açıktaki gemiye uzun uzun bakmaktadır. Sadece kıyamet habercisi İsrafil'in Sur'u üflemesini çağrıştıran gemi düdüğü sesi ve doğal sesler duyulur. Bunun dışında konuşma veya hareket yoktur. Bu bizi görüntüler üzerine düşünmeye itmektedir. Acaba kasabalı neden gemiye bakmaktadır? Bir şey mi beklemektedir? Ne görmektedirler? Yönetmen özelikle de filmin açılışında neden böyle bir görüntü tercih etmiştir? İşte bu soruları sormaya başladığımızda düşünce devreye girmeye ve karşılıklı olarak görüntü imajlar da bizlere bir şeyler anlatmaya başlamaktadır. Burada İsrafil'in suruyla birlikte filmin sonraki gelişmeleri de düşünüldüğünde kasabalının kıyameti, bir çeşit 'sonu beklediği' söylenebilir. Bu sahne kıyamet sonunun bir başlangıcı olarak analiz edilebilir. Merkezdeki görüntü sesle desteklenerek kullanılmış ve anlam yaratılmıştır. Bu sahneden hareketle filmde genel olarak ses kullanımın görüntünün önüne geçmeyen yapısıyla saf sinemaya uygunluk gösterdiği görülmektedir. Film boyunca seslerin sade ve minimal kullanımı dikkat çeker. Ancak bu sahnede gelen gemi düdügü sesinin akış içerisinde kısmen baskın ve görülen sahnenin doğallığına aykırı kullanımı sebebiyle yer yer saf sinema dışı bir kullanıma sürüklendiği de görülmektedir. 


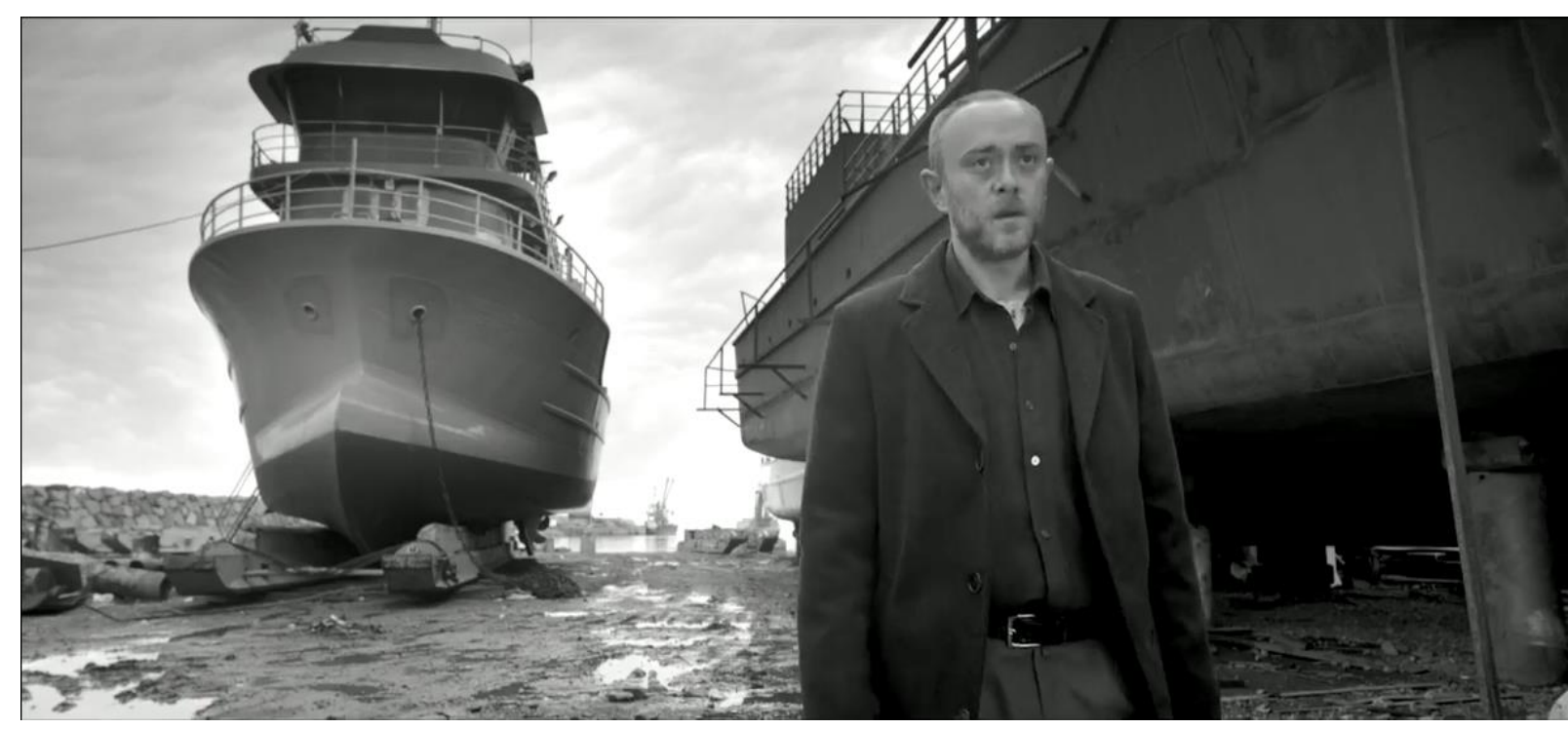

Görsel 2 : Kasabaya iş aramaya gelen adam büyük gemilerin arasında küçücük görünür.

Kasabaya iş aramak amaciyla sonrada gelen karakter kasabada huzursuz bir hayat sürmektedir. Kasabalı ona bazen sanki tüm bu olayların sorumlusuymuş gibi bazense tüm bu olaylardan onları kurtaracak tek kişiymiş gibi davranmaktadır. Aslında kasabada farklı işlerde çalışıp farklı kamusal alanlara girse de o yalnız bir karakterdir. Bir çeşit ötekidir. Aynı zamanda da hastadır. Bu durum gemilerin olduğu sahnelerde seyirciye hissettirilmeye çalışılır. Kıyıdaki büyük devasa gemilerin arasında küçücük kalmıştır. İçinde bulunduğu tüm bu durumlarla düşünüldügünnde karakterin içinde bulunduğu fiziksel durum ve ruhsal dünyası bu şekilde görüntülerle aktarılmaya çalışılır. Zaten genel çekimlerin çoğunlukla karakterin dışında ve nesnel bir şekilde verilmesi ve seçili görüntülere toplumsal ve fiziksel hayatın eklenmesiyle ve bunun öne çıkarılmasıyla bu anlam yaratılmaktadır (Ryan \& Lenos, 2012: 68). Görüntü imajlar film boyunca altı çizilen durumları tek bir sahnede iletme gücüne sahip şekilde kullanılmıştır.

Ayrıca yukarıdaki tartışmalar ışığında filmde kullanılan renk tercihinin tıpkı örneği verilen Roma filminde olduğu gibi sinematografik unsurları ortaya çıkaran yapısıyla kullanılması da görüntülerin merkezi konumunu güçlendirmesi bakımdan filmi saf sinemaya daha da yakınlaştırmaktadır. Bu kullanımla görüntüye eşlik eden tüm unsurular ikinci plana itilerek görüntülerin anlamı ve etkisi güçlendirilmiştir. Saf sinema tartışmasında görüntü merkezli bir sinema anlayışı göze alındığında bu durumun saf sinema anlayışını pekiştirdiği görülmektedir. Bunun yanı sıra sinemanın ilk yıllarındaki siyah- beyaz kullanımı çağrıştırması açısında da izleyicide saf sinema izlenimi pekişmektedir. 


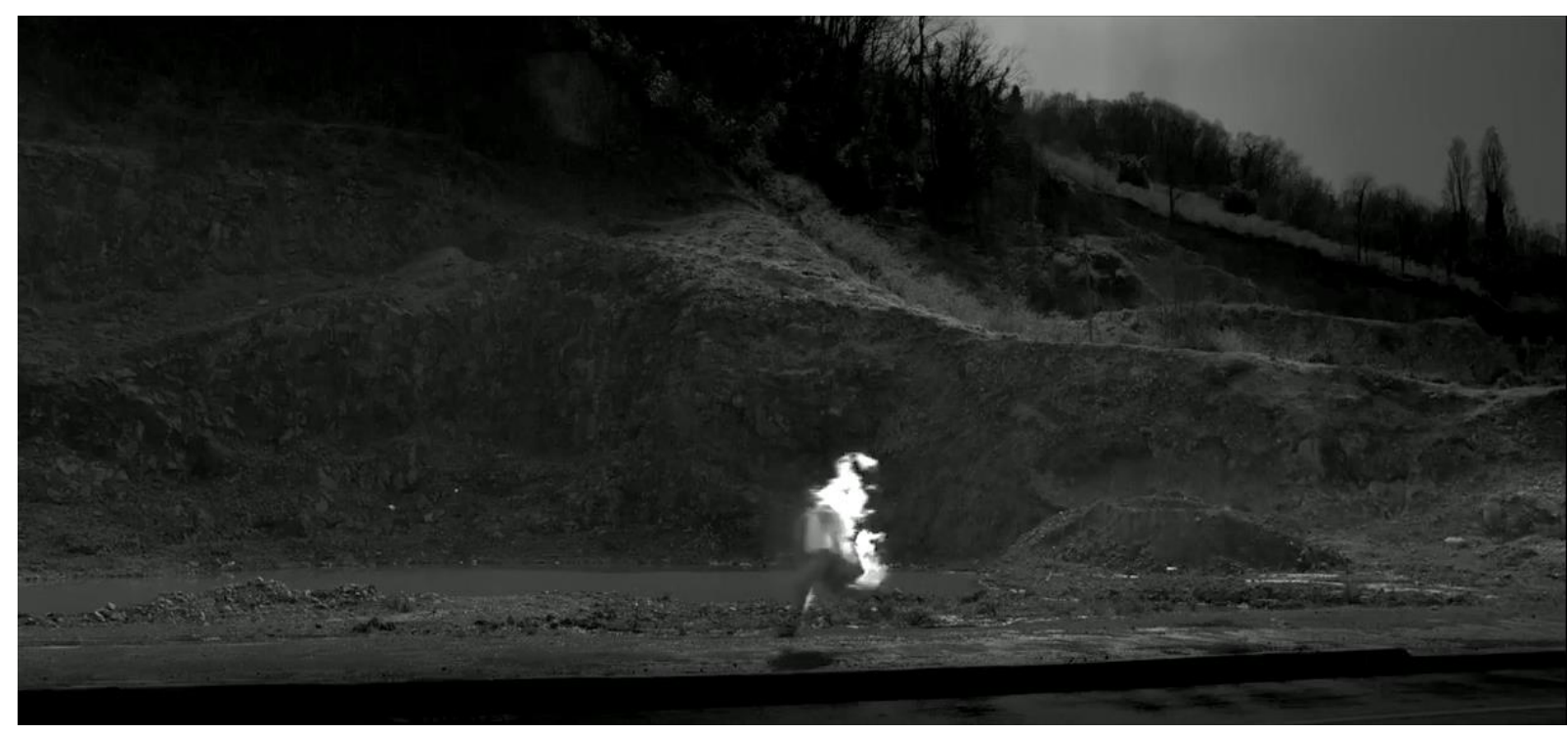

Görsel 3 : Yanarak koşan adam

Filmde dikkat çeken bir diğer sahne ise nerden geldiği ve neden yandığı bilinmeyen koşan adamın olduğu sahnedir. Zaten kasabada kimsenin sebebini bilmediği yangılar çıkmaktadır. Bu yangın metaforu filmin bir kıyamet filmi olduğu düşünülürse anlamlı hale gelmektedir. Ayrıca bir gözünün takma olduğunu bildiğimiz karakterin itfaiyede çalıştığ1 bilinmektedir. Aslında kötü olan bu karaktere yani Deccal'e ateşle ilgili bir görev verilmiştir. Ayrıca benzin bidonlarının Deccal tiplemesinin evinde görülmesi onun yangın ve ateşle olan ilişkisini güçlendirmektedir. Dolayısıyla bu görüntülere filmin çok katmanlı yapısındaki halkalardan biri olan Mehdi- Deccal hikâyesi üzerinden bakıldığında karşımıza şu denklem çıkmaktadır, başka bir değişle görüntüler bize şu kelimeleri fısıldamaktadır: Deccal, ateş, kıyamet, cehennem ve sonun yaklaşması. Bunun dışında yanarak koşan adam sahnesi ilk bakışta illüzyon halesi içinde saflığın dışına çıkan bir görünüm sergilese de, görüntülerle bir anlam yaratma amacında olması ve saf sinemanın da sinema özüne atıfla görüntünün merkezi konuma karşılık gelmesi sebebiyle saf sinemaya uygunluk göstermektedir. Sahne ancak gerçeklik temelli bir saf sinema anlayışı ile değerlendirildiğinde saf sinemanın dışında birakılabilir. 


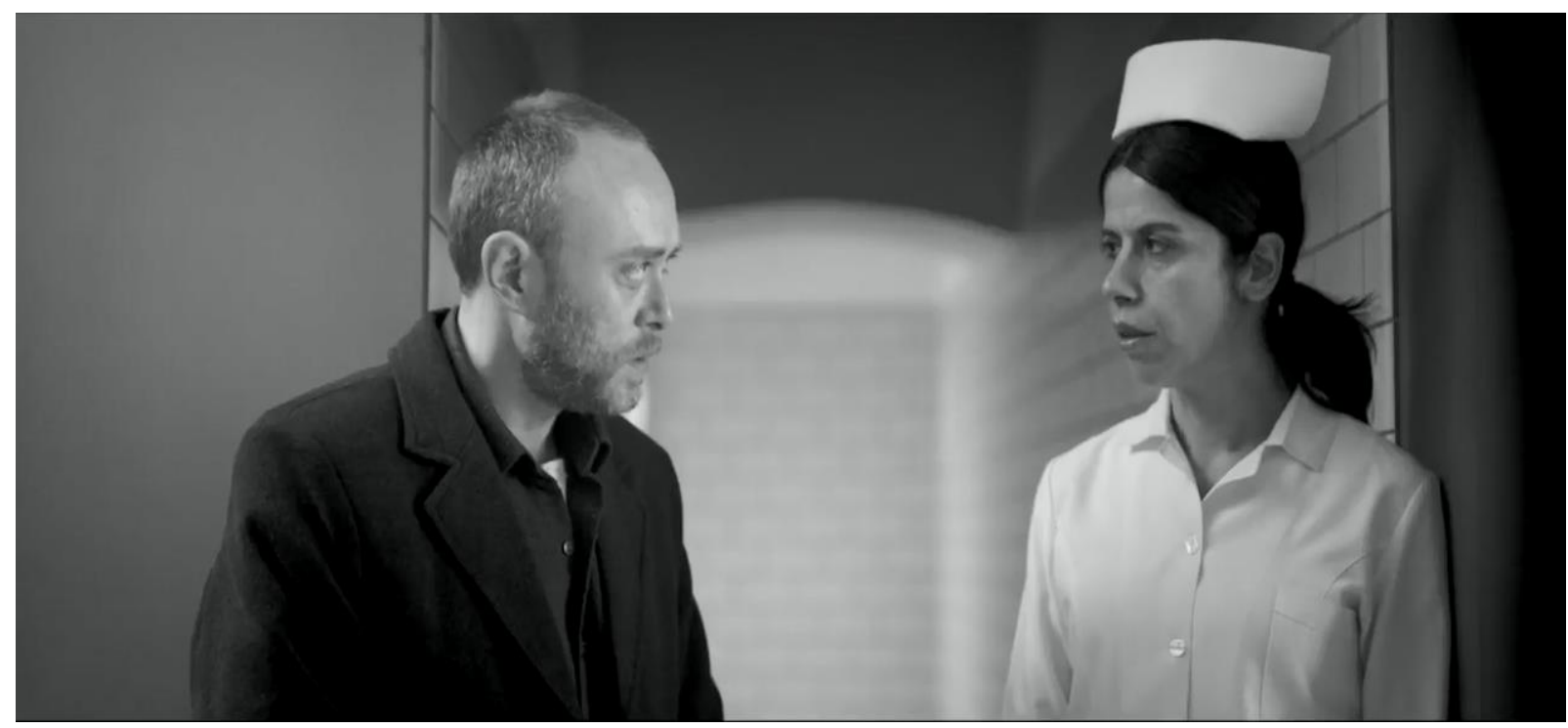

Görsel 4 : Dispansere giden adamın sırtında hemşire bir iz fark eder. Bu kasabalı tarafindan kurtarıcı olduğunun bir göstergesidir.

Kasabaya sonradan gelen adam ciğerlerinden hastadır. Tedavi için dispansere gider. Ciğer filmi çekilirken hemşire sırtından yaprak gibi bir iz olduğundan bahseder. Bu iz hemşire ve kasabalı için onun kurtarıcı olduğunun çok büyük bir işaretidir. Kasabalı ve devletin üst kademeleri tarafından sürekli konuşmaktadır. Ancak bu sahnede ve film boyunca seyirciye bu iz gösterilmez. Bu noktada adam izi gören tuhaf kasabalı tarafından kurtarıcı olarak görülürken film boyunca izi hiç göremeyen seyircinin kafasında soru işaretleri belirir. Acaba iz var mıdır? O bir kurtarıcı mıdır? Burada dikkat edilmesi ve altı çizilmesi gereken önemli bir nokta vardır. $O$ da görüntüleri merkeze yerleştirerek anlam yaratırken aslında bunun içinde bu görüntülerde bir eksilti yaratılarak da farklı anlamlar yaratılıp farklı sorgulama yollarının açılabileceğidir. Burada izin olmayışındaki eksilti muğlaklık yaratarak farklı sorular sormamıza imkân vermektedir. Başka bir değişle anlam sadece yoğun bir görüntü akışıla değil bu görüntülerde yaratılan eksiltilerle de yaratılabilir.

Bu noktada hikâye unsuru içerisinde görüntülerin genel kullanımının dışında da eksilti yaratılarak- anlam yaratımından bahsederken hikâye unsurunun film bağlamında kullanımının saf sinemaya uygunluğuna da değinmek gerekmektedir. Yönetmenin ifade ettiği gibi hikâye olağanüstü olsa da onu anlatma biçiminin olağan oluşu sebebiyle filmin saf sinemaya uygun düştüğü görülür. Tartışma boyunca görüntülerin merkezi konumda değerlendirilmesinin saf sinemaya uygunluğu düşünüldüğünde bu nokta da hikâyenin görüntüyü destekleyen bir unsur olarak kullanılması filmi saf sinema sınırları içine alan bir başka unsurdur. 


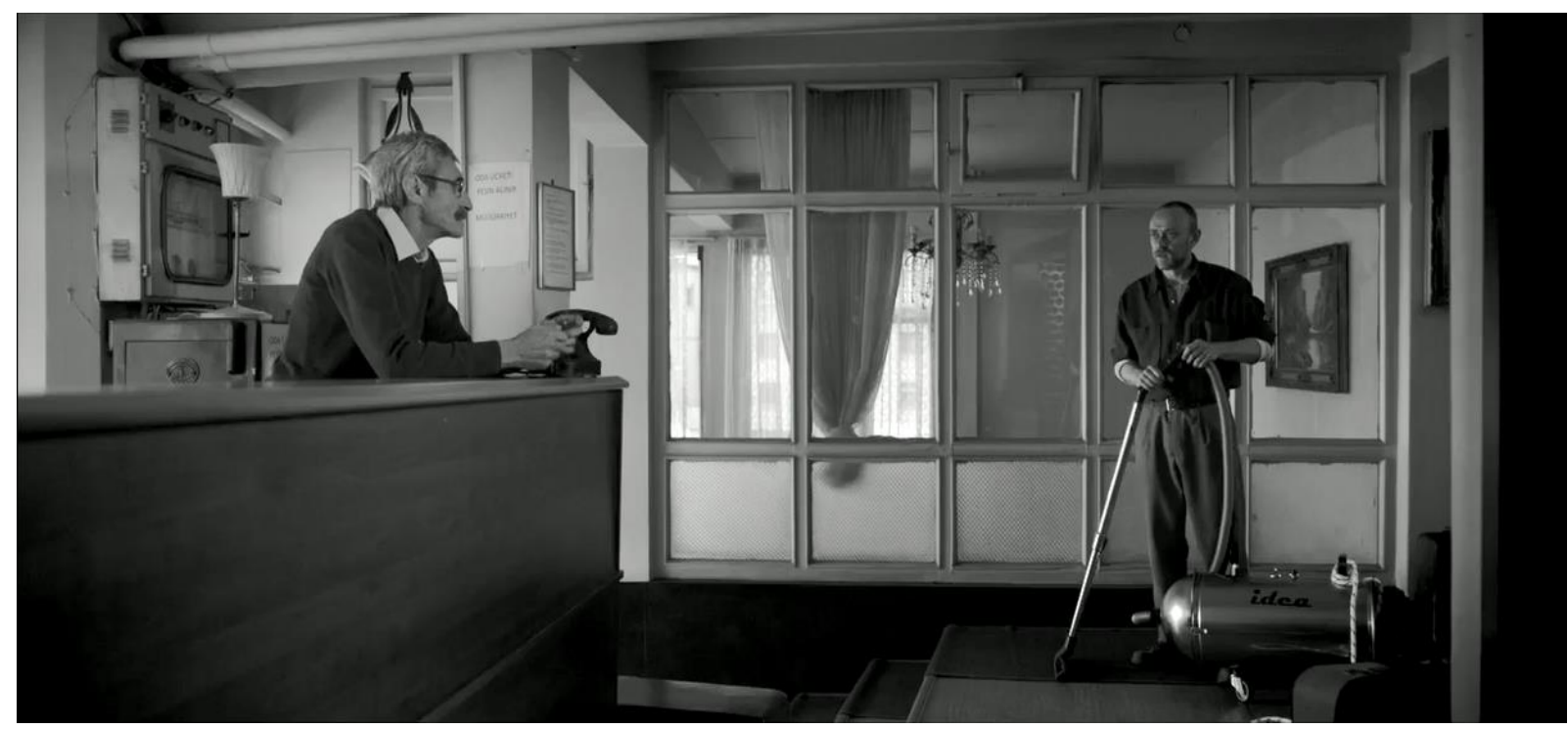

Görsel 5 : Kurtarıcı olduğu düşünülen adamın çalıştı̆̆ı otelde de sorgulanması sürer.

Kasabaya iş aramak için sonradan gelen ve kasabalı tarafından sırtındaki bir izden dolayı sürekli kurtarıcı olduğu düşünülen karakter yatacak yer sorununu çözmek amacıyla bir otelde çalışmaktadır. Bunun karşılığında otel sahibi ona kalması için bir oda verir. Temizlik yapıldığı bu sahnede temizlik için alınan yeni elektrik süpürgesi aniden durur ve çalışmaz. İkisi de bozulduğunu düşünür. Bu sırada otel sahibi onun kurtarıcı olduğuna inanmadığını söylemektedir. Bunun üzerine tam o an adamın elindeki elektrik süpürgesi çalışmaya başlar. Bu noktada zihinde tekrar kurtarıcı sorgulamaları başlar. Ayrıca önemli bir nokta da plan içerisinde özel olarak yerleştirilmiş elektrik süpürgesinin üzerindeki "idea" yazısıdır. Kasabalı elinde idea yazısı bulanan bir süpürge tutan adamdan bir idea-fikir beklemektedir. Makinenin parlaklığına bakılacak olursa beklenenin parlak bir fikir olduğu açıktır. Bunun dışında yukarıdaki saf sinema bağlamında tartışılan oyunculuk konusu filmin genel yapısı ve özelde bu sahne üzerinde değerlendirilecek olursa tiyatrovari bir oyunculuk biçiminin tamamen dışlandığı bunun yerine sinemaya özgü doğal ve sade bir oyunculuğun tercih edildiği görülmektedir. Bu anlamda film oyunculuk açısından da saf sinemaya uygunluk göstermektedir.

Filme son olarak geniş bir perspektifle Bela Balazs, Kracauer ve Gilles Deleuze'ün sinemanın özünü aradığımız düşünceleriyle bakacak olursak zaten fiziksel varoluşu hareket halinde kaydetme durumunu her filmde olduğu gibi içinde barındırmaktadır. Ancak bunun yanı sıra sinemaya ait araçları sinematik olan kavramında olduğu gibi kullanmakta ve görüntülerin ifşa işlevini de yerine getirmektedir. Film Kracauer'nun ifadeleriyle normalde görünmeyen şeyleri bize göstermekte ve bilincimizi afallatmaktadır. Ayrıca Balazs'dan hareketle yeri doldurulamaz ifade aracı olan görüntü merkezi bir konuma oturtulmuştur. Deleuze'den hareketle ise filmin hareket ve zaman imge kavramlarının görüntülerin faklı şekillerde kullanımları olarak ele alındığında merkezi noktanın yine görüntüler olduğu düşünülürse bu nokta da filme uyumlu görünmektedir.

Yol Kenarı filmi bunların dişında Tayfun Pirselimoğlu'nun deyimiyle 'numara yapmayan' seyirciyi kandırma yoluna gitmeyen bir yönü olması sebebiyle de saf sinemanın 
bir örneği olarak sayılabilmektedir. Bunun yanında film, hikâye olağanüstü gibi görünse de bunu olağan bir şekilde anlatarak yine illüzyon yapmayı reddetmiş ve gerçekliği açıkça anlatma yoluna gitmiştir. Bu durum ifade araçlarının yalın bir şekilde kullanılması anlamına gelir. Bu yalınlık durumu saf sinema için önemli bir noktadır. Başka bir değişle saf sinemanın sırrı Tarkovski'nin ifadesi de eklenirse "ifade araçlarının tutumluluğu"nda yatmaktadır. Ayrıca filmin siyah-beyaz oluşu saf dokusuna katkı sağlamıştır. Bu siyahbeyazın getirdiği saflık sinemanın ilk yıllarındaki başyapıtlardan gelen bir saflık hissidir. Siyah-beyaz olarak üretilen güncel filmler sinemanın ilk yıllarındaki bu özelliği -renkli imkânlar varken- kullanması dolayısıyla saflık hissiyatı yaratır. Tabii ki siyah-beyaz kullanım sadece bu amaçla kullanılmamaktadır. Bu filmde olduğu ve yönetmenin de ifade ettiği gibi "hikâye bunu istedi" durumu da ortaya çıkabilir. Yapılan bu genel değerlendirme sonucunda görülebilir ki Yol Kenarı filmi saf sinemaya özgü kodları içerisinde barındırmaktadır.

Filmin genel itibariyle saf sinemaya uygunluğu ortaya koyulmaya çalışılmıştır. Ancak filmin saf sinemaya uygun olmayan yönlerinin de ne şekilde değerlendirileceği ortaya konulmalıdır. Bu bağlamda filmin gerçeklik temelli bir saf sinema anlayışı ile değerlendirilmesi yapıldığında filmdeki bazı gerçeküstü görüntü imajların filmi saf sinemanın dışına taşıyan unsurlar olduğu görülebilir. Ayrıca buradan hareketle bu durumda gerçekliğe ters düşecek tüm sinematik unsurlar sebebiyle film saf sinemanın dışında bir noktaya konumlandırılabilmektedir.

\section{Sonuç}

Sonuç olarak saf sinema kavramının sınırlarını çizmek ve kavram hakkında bir tanımlamaya gitmek zor olsa da saf sinema kavramı bu özelliğinin yanında farklı konumlanma noktalarından tartışılabilmekte ve bu konumlanma noktalarına göre belli tanımlamalara imkân sağlamaktadır. Bu tanımların ulaşacağı nihai nokta sinemanın kendi olanakları ile sinema yapmak olarak ifade edilebilecek bir noktaya karşıllk gelmektedir. Ancak bu tanımlama nihai olmasının yanında bazı muğlaklıkları da beraberinde getirmektedir. Bu sebepten saf sinemayı tartışırken belirli konumlanma noktalarından hareket etmek kavramı netleştirmek adına faydalı olacaktır.

Bu çalışma özelinde bu netleştirmenin ancak sinemanın özü yapılan bir yolculukla mümkün olacağı ortaya konulmuştur. Bu yolculuk Bela Balazs, Siegfried Kracauer ve Deleuze'ün kavramları ve düşünceleri üzerinden felsefik bir çizgide devam etmiştir. Yolculuğun sonucunda Balazs, Kracauer ve Deleuze'ün sinemaya dair düşünceleri konu bağlamı değerlendirildiğinde sinemanın özünün görüntüler, görüntü imajlar olduğu görülmektedir. Bu bağlamda saf sinemanın da görüntüler üzerine yükselen, görüntülerin merkezde olduğu bir sinema anlayışı olduğu ortaya çıkmaktadır. Başka bir değişle saf sinema, sinemanın özüyle olan bağını - görüntülerin merkezi konumunu- koruduğu sürece saf kalabilir. Görüntülerin merkezde olması düşüncesi, görüntülerin filmdeki diğer tüm araçların üzerinde konumlandırılması anlamına gelmektedir. Bu konumlandırma diğer sanatlara ait veya ortak medyumlar olan ses, müzik, oyunculuk, olay örgüsü ve hikâyenin görüntüleri destekleyecek şekilde kullanılması anlamına gelir. Ayrıca görüntülerin bu şekilde kullanılması bir şey anlatma derdinde olan filmde bu anlatma rolünün görüntülerin üstlenmesi anlamına gelir. Yani görüntüler bir şeyler anlatma derdindedir. Görüntü merkezli bu anlayışının dışında saf sinemaya gerçeklikle bağın korunduğu bir sinema anlayışla da 
bakılabilmektedir. Bu farklı bir konumlanma noktasına karşılık gelir. Filmler gerçeklikle veya Kracauer'un da ifade ettiği şekilde fiziksel varoluşla bağını koruduğu sürece sinematiktir (2015). Ardından saf sinema için önemli olan temel noktalardan biri olan yalınlık gelmektedir. Tarkovski'nin ifade araçlarının tutumluluğu olarak ifade ettiği bu yalınlık saf sinemanın karakteristik bir özelliği olarak karşımıza çıkmaktadır. Bu yalınlık sinematik araçların yalın, sade kullanılmasıdır. Dolayısıyla tüm saf sinema tartışmaları göz önünde bulundurulduğunda, saf sinema görüntülerin merkezde olduğu, gerçeklikle bağını koruyan ve bunu yaparken kendine has ifade araçlarını yalın bir üslupla kullanan bir sinema anlayışı olarak karşımıza çıkmaktadır. Saf sinema hikâye anlatan bir sinema değildir; görüntülerin bizzat hikâyenin kendisi olduğu bir sinemadır.

Konuya farklı açılardan bir bakış getirebilmek ve tartışma alanını genişletmek amacıyla saf sinemaya Dogma 95 ve örnek olarak analiz edilen Yol Kenarı filminin yönetmeni Tayfun Pirselimoğlu'nun görüşleri de eklenmiştir. Bunun sonucunda Dogma 95'in saf sinemaya ulaşma yolunda bir çaba olarak görülebileceği ortaya koyulmuştur. Ancak ortaya attıkları manifestonun bazı maddelerinin bu çabaya çok uzak durduğu da görülmektedir. Dogma 95 gerçeklik merkezli bir saf sinemaya dönüş çabası olarak görülebilir. Tayfun Pirselimoğlu'nun görüşleri ise konuya faklı bir bakış açısı getirmiştir. Pirselimoğlu, saf sinemayı 'numara yapmayan' bir sinema olarak nitelemiştir. Başka bir değişle seyirciyi kandırma yoluna gitmeyen bir sinema anlayışı. Bu nokta saf sinema-seyirci ilişkisi bakımından önemli bir nokta olarak karşımıza çıkmaktadır.

Bu tartışmalar ışığında saf sinemanın olanaklılığı konusu da bir soru olarak karşımıza çıkmaktadır. Bu konuda gelişen küresel sinema endüstrisi koşulları düşünüldüğünde ortaya çıkan şartlar altında filmler rekabetçi bir ortamda üretildiğinden sinema üreticileri saf bir sinema anlayışı yerine genel olarak bu anlayışın tersine sanat tarafı zayıf, ticari tarafı ağır basan filmler yapmayı tercih edebilmektedir. Bu durum sinemanın sanat tarafının yanında bir endüstri olduğu gerçeği de göz önünde bulundurulursa kısmen anlaşılır bir durumdur. Saf bir sinema her zaman olanaklı görünmektedir. Ancak mevcut koşullar altında sinemanın sadece saf bir yapıda üretilmesini beklemek de yanlış olacaktır.

Örnek olarak seçilen Yol Kenarı filmi ise Türk sinemasında bir saf sinema örneği olarak karşımıza çıkmaktadır. Yukarıda belirtilen saf sinemaya ait bütün sinematografik kodları içinde barındırması, yalınlığı ve bilinçli olarak tercih edilen siyah-beyaz renk tercihi bu saf sinema izlenimini ortaya çıkarmaktadır. Siyah- beyaz renk tercihi yalınlıkla birleştiğinde kuramsal bir yanı olmasa da bize sinemanın ilk yıllarını sezdiren bir atmosfer sunmaktadır. Tüm bunlar dolayısıyla Yol Kenarı film bir saf sinema örneği olarak görülebilir.

Son olarak saf sinema konusunun anlaşılması bakımından hayati öneme sahip bir diğer nokta ise şudur: bugün renk, müzik, ses, hikâye, vs. unsurlarının başarılı bir şekilde yoğun olarak kullanıldığı bir filmin saf sinema olup olmayacağı yönündeki sorulardır. Aslında cevap açıktır. Bu filmler sinemanın başarılı örnekleri olabilirler ancak saf sinema olarak tanımlanamazlar. Başarılı sinema filmi örnekleri sinema sanatı adına çok değerli bir noktadır ancak saf sinema farklı bir noktada konumlanır. Hikâyenin, müziğin merkezi bir konumda olduğu bir film sinemanın başarılı bir örneği olarak sinema tarihindeki yerini alabilir ama bu filmi saf sinema olarak değerlendirmek yanlış olacaktır 


\section{Kaynakça}

Arnheim, R. (2010). Sanat Olarak Sinema, İstanbul: Hil Yayın.

Balazs, B. (2013). Görünen İnsan. Oya Kasap (Çev.) İstanbul: Say.

Bresson, R. (2012). Sinematograf Üzerine Notlar. Nilüfer Güngörmüş (Çev.). İstanbul: Küre.

Coppola, F, F. (Yapımc1) \& Coppola, F, F. (Yönetmen). (1979). Apocalypse Now [Sinema Filmi]. ABD: Omni Zoetrope.

Cuarón, A., Rodriguez, G., Celis, N. (Yapımc1) \& Cuarón, A. (Yönetmen). (2018). Roma [Sinema Filmi]. Meksika: Participant Media, Esperanto Filmoj.

Deleuze, G. (2003). İki Konferans. Ulus Baker (Çev.). İstanbul: Norgunk.

Deleuze, G. (2014). Sinema I, Hareket- İmge. Soner Özdemir (Çev.) İstanbul: Norgunk.

Flaherty, J, R. (Yapımc1) \& Flaherty, J, R. (Yönetmen). (1922). Nanook of The North [Sinema Filmi]. ABD: Pathepicture.

Hitchcock, A., Reville, A. (Yapımc1) \& Hitchcock, A. (Yönetmen). (1960). Psycho [Sinema Filmi]. ABD: Paramount Pictures, Universal Pictures.

Karmitz, M. (Yapımcı) \& Kieślowski, K. (Yönetmen). (1993). Bleu [Sinema Filmi]. Fransa: Eurimages, France 3 Cinêma, Canal+.

Karmitz, M. (Yapımc1) \& Kieślowski, K. (Yönetmen). (1994). Blanc [Sinema Filmi]. Fransa: France 3 Cinêma, Canal+.

Karmitz, M. (Yapımc1) \& Kieślowski, K. (Yönetmen). (1994). Rouge [Sinema Filmi]. Fransa: France 3 Cinêma, Canal+.

Kracauer, S. (2015). Film Teorisi. Özge Çelik (Çev.). İstanbul: Metis.

Lumiêre, A,M,L,N. \& Lumiêre, L,J. (Yönetmen). (1895) La Sortie des Usines Lumière à Lyon [Sinema Filmi]. Fransa.

Öztürk, S. (2018). Sinema Felsefesine Giriş. Ankara: Ütopya.

Özarslan, Z. (Ed.) (2015). Sinema Kuramları 1. İstanbul: Su.

Özarslan, Z. (2015) (Editör). Sinema Kuramları 2. İstanbul: Su.

Pirselimoğlu, T., Moustakas, N., Ersen, V., Kokolaki, N. (Yapımc1), \& Pirselimoğlu, T. (Yönetmen). (1994). Yol Kenarı [Sinema Filmi]. Türkiye: Mitra Filmcilik.

Pirselimoğlu, T. (2018). (Yönetmen) Yapılan Kişisel Görüşme.

Ryan, M., Lenos, M (2012). Film Çözümlemesine Giriş. Emrah Suat Onat (Çev.). Ankara: Deki. 
Sütcü, Y, Ö. (2015). Gilles Deleuze'de İmge Hareketi Olarak Sinemanın Felsefesi. Bursa: Sentez.

Tarkovski, A. (2008). Mühürlenmiş Zaman. Füsun Ant (Çev.). İstanbul: Agora. 